Journal of Development and Social Change, Vol. 3, No. 1, April 2020

p-ISSN 2614-5766, https://jurnal.uns.ac.id/jodasc

\title{
POLA PEMBENTUKAN PADA PERILAKU TOLERANSI BERAGAMA ANAK (Studi Kasus di LKSA Nur Hidayah Kecamatan Laweyan Kota Surakarta)
}

\author{
Fathiana Vellayati $^{1}$, Rahesli Humsona ${ }^{2}$ \\ Program Studi Sosiologi Fakultas Ilmu Sosial dan Politik \\ Universitas Sebelas Maret Surakarta Indonesia \\ Email $^{1}$ : fathiana.vela@gmail.com, Email²: rahesli64@staff.uns.ac.id
}

\begin{abstract}
This study aims to determine the formation of Nur Hidayah LKSA in fostering religious tolerance in children in the community. The theory used in this study is the social practice of Pierre Bourdieu, the formula of social parktik theory is (habitus + capital) x realm. This research is a type of qualitative research with a case study approach. Data collection techniques used are (1) non-participatory observation techniques, namely data collection through nonverbal observations (2) unstructured interview techniques, asking questions jumping from time to time or from one topic to another topic (Slamet, 2006), (3) documentation study, which documented the results of interviews and then made an interview transcript of the recordings and personal notes during the study. The sampling technique in this study used a purposive sample. Data validity uses source triangulation to compare data. Data analysis techniques consist of three activities that occur simultaneously, namely: data reduction, data presentation, drawing conclusions.

This study shows that (1) the concept of habitus can be seen through LKSA Nur Hidayah provides the formation of religious tolerance in children given through studies twice a week besides LKSA Nur Hidayah teaches about religious and social life, (2) social capital undertaken LKSA Nur Hidayah can give birth to an open attitude and accept differences, peace and tolerate the inconveniences of life. That is because between the community and LKSA Nur Hidayah trust each other, running the norms that apply in the community. LKSA Nur Hidayah frees her foster children to make friends with anyone, but still maintains her own faith and is not influenced by others, (3) cultural capital that is realized is the community invites orphanage children to mutual cooperation and children join mutual cooperation with the community, (4) Symbolic capital is a palebelan or assessment of others, a pretty good citizen education and has a modern mindset so that tolerance can be created between Nur Hidayah LKSA and the community, (5) economic capital is closely related to finance, the obligation of Nur Hidayah LKSA is to finance foster children's schooling and paying caregivers and holding social services.
\end{abstract}

Keywords: Formation of Attitude, Tolerance, Religious Tolerance, Children

Abstrak: Penelitian ini bertujuan untuk mengetahui pembinaan LKSA Nur Hidayah dalam menumbuhkan pada perilaku toleransi beragama pada anak di kalangan masyarakat. Teori yang di gunakan dalam penelitian ini adalah praktik sosial dari Pierre Bourdieu, rumus dari teori parktik sosial adalah (habitus+modal)x ranah. Penelitian ini merupakan jenis penelitian 
kualitatif dengan pendekatan studi kasus. Teknik pengumpulan data yang digunakan adalah (1) teknik observasi tidak berpartisipasi yaitu pengumpulan data melalui pengamatan yang bersifat nonverbal (2) teknik wawancara tidak terstruktur, pengajukan pertanyaan secara meloncat-loncat dari waktu ke waktu atau dari topik satu ke topik yang lain (Slamet, 2006), (3) studi dokumentasi, dimana mendokumentasikan rekaman hasil wawancara kemudian dibuat sebuah transkip wawancara dari hasil rekaman dan catatan pribadi selama penelitian. Teknik pengambilan sample pada penelitian ini menggunakan sampel purposive. Validitas data menggunakan triangulasi sumber untuk membandingkan data Teknik analisis data terdiri dari tiga alur kegiatan yang terjadi secara bersamaan, yaitu: reduksi data, penyajian data, penarikan kesimpulan.

Penelitian ini menunjukkan bahwa (1) konsep habitus dapat dilihat melalui LKSA Nur Hidayah memberikan pembentukan sikap toleransi beragama pada anak yang diberikan melalui kajian dua kali dalam satu minggu selain itu LKSA Nur Hidayah mengajarkan tentang kehidupan beragama dan sosial, (2) modal sosial yang dilakukan LKSA Nur Hidayah dapat melahirkan sikap terbuka dan menerima perbedaan, kedamaian dan mentoleransi ketidaknyamanan hidup. Hal tersebut karena antara masyarakat dan LKSA Nur Hidayah saling percaya, menjalankan norma yang berlaku di masyarakat. LKSA Nur Hidayah membebaskan anak asuhnya untuk berteman dengan siapapun, tetapi tetap menjaga akidah diri sendiri dan tidak terpengaruh oleh orang lain, (3) modal budaya yang terwujud adalah masyarakat mengajak anak panti untuk gotong royong dan anak-anak mengikuti gotong royong dengan masyarakat, (4) Modal Simbolik merupakan palebelan atau penilaian terhadap orang lain, pendidikan warga yang cukup bagus dan memiliki pemikiran yang modern sehingga toleransi dapat tercipta diantara LKSA Nur Hidayah dengan masyarakat, (5) modal ekonomi erat kaitannya dengan finansial, kewajiban dari LKSA Nur Hidayah yaitu membiayai sekolah anak asuh dan membayar pengasuh serta mengadakan bakti sosial.

Kata Kunci: Pembentukan Sikap, Toleransi, Toleransi Beragama, Anak

\section{PENDAHULUAN}

Hidup bermasyarakat berarti hidup berdampingan dengan orang lain, dan hidup berdampingan dengan orang lain memiliki konsekuensi untuk mau menerima setiap kondisi yang terjadi diantara berbagai manusia yang ada disekitar. Tidak menutup kemungkinan orang yang ada disekeliling kita terdapat orang yang berbeda agama. Maka dalam hal ini memerlukan pemahaman tentang kerukunan umat beragama. Kerukunan dalam hal ini dapat dilandasi dengan sifat saling menghormati antar umat beragama, yang kemudian diharapkan muncul komunikasi yang bersifat kemanusiaan dengan sebaik-baiknya.

Peran keluarga sangat penting untuk membentuk kepribadian anak. Keluarga merupakan lembaga pertama dan utama dalam membentuk perkembangan anak. Maka dari itu keutuhan keluarga sangat dibutuhkan oleh anak. Namun tidak semua anak memiliki keluarga utuh dan menerima pembinaan dari orang tuanya. Ada pula dari mereka sejak kecil tidak memiliki orang tua atau tidak memiliki orang tua yang utuh atau memiliki kondisi orang 
tua yang tidak memungkinkan untuk memberikan pembinaan dan pemeliharaan kepada anak karena keterbatasan materi dan ekonomi,maka anak tersebut dipelihara oleh panti asuhan Panti asuhan berperan sebagai pengganti keluarga dalam memenuhi kebutuhan anak dalam proses perkembangannya. Pada saat anak melewati masa remaja pemenuhan kebutuhan fisik,psikis,sosial sangat dibutuhkan dalam perkembangannya dikarenakan masa remaja merupakan masa transisi dari kanak-kanak menuju dewasa. Dalam masa tersebut anak memiliki masalah terkait dengan kebutuhan fisik, psikis dan sosial.

Kenyataan yang tidak dapat dipungkiri bahwa Negara Indonesia merupakan salah satu negara multikultural terbesar di dunia. Hal ini dapat dilihat dari kondisi sosiokultural, agama, kelompok etnis, budaya, maupun geografis yang begitu beragam dan luas, sehingga masyarakat dan bangsa Indonesia secara sederhana dapat disebut sebagai masyarakat "multikultural". Menurut Luthfia tahun 2019, berdasarkan data Badan Pusat Statistik, Sensus Penduduk 2010 menyebut ada 1.331 kelompok suku di Indonesia. Kategori itu merupakan kode untuk nama suku, nama lain/alias suatu suku, nama subsuku, bahkan nama sub dari subsuku. Sekarang ini, jumlah pulau yang ada di wilayah Negara Kesatuan Republik Indonesia (NKRI) sekitar 13.000 pulau besar dan kecil. Populasi penduduknya berjumlah lebih dari 200 juta jiwa. Terkait jumlah bahasa di Indonesia, Badan Pengembangan dan Pembinaan Bahasa Kementerian Pendidikan dan Kebudayaan atau Badan Bahasa telah memetakan dan memverifikasi 652 bahasa daerah yang berbeda.,

Indonesia merupakan negara yang penduduknya mayoritas beragama Islam . Namun Indonesia bukanlah negara Islam ,yang hanya memakai hukum dan perundang-undangan Islam. Indonesia memiliki agama Islam, Hindu, Budha, Khonghucu, Kristen, Katolik dan berbagai kepercayaan yang dianut oleh masyarakat. Keanekaragaman tersebut tidak tercipta tanpa adanya dukungan dari elemen masyarakat dan dukungan dari pemerintah. Upaya pemerintah dalam menumbuhkan sikap beragama yang harmonis telah dilakukan diberbagai kegiatan, diantaranya menumbuhkan sikap inklusi dan toleran antar pemeluk agama dan ras.

Table 1.1 Komposisi Agama di Indonesia

\begin{tabular}{|l|l|l|}
\hline Agama & Jumlah Penduduk & Persentase \\
\hline Islam & 207.176 .162 & 87,18 \\
\hline Kristen & 16.528 .513 & 6,96 \\
\hline Katolik & 6.907 .873 & 2,91 \\
\hline Hindu & 4.012 .116 & 1,69 \\
\hline Budha & 1.703 .254 & 0,72 \\
\hline Khong Hu Cu & 117.091 & 0,05 \\
\hline Lainnya & 299.617 & 0,13 \\
\hline Tidak Terjawab & 139.617 & 0,06 \\
\hline Tidak Ditanyakan & 757.118 & 0,32 \\
\hline Jumlah & 237.641 .326 & 100 \\
\hline
\end{tabular}

Sumber: Badan Pusat Statistik Sensus Penduduk 2010 
Berdasarkan sensus penduduk tahun 2010 oleh BPS Indonesia, memang ada sekitar 1 juta lebih masyarakat Indonesia yang tidak diklasifikasikan agamanya. Disinyalir, sebagian dari mereka adalah penganut kepercayaan asli leluhur. Sesuai sensus BPS 2010, agama yang paling banyak dianut oleh penduduk Indonesia adalah agama Islam, Kristen, Katolik, Hindu, Budha, Khong $\mathrm{Hu} \mathrm{Cu}$ dan lainnya. Pemeluk agama Islam pada tahun 2010 sebanyak 207,2 juta jiwa (87,18 persen). Pemeluk agama Kristen 16,5 juta jiwa (6,96 persen). Lalu pemeluk Katolik sebanyak 6,9 juta jiwa (2,91 persen). Sedangkan pemeluk agama Hindu yakni 4.012.116 jiwa (1,69 persen). Agama Budha sebanyak 1.703.254 jiwa (0,72 persen). Kemudian, agama termuda yang diakui pemerintah Indonesia, Khong $\mathrm{Hu} \mathrm{Cu}$, dianut sekitar 117,1 ribu jiwa (0,05 persen).

Penanaman nilai-nilai kebersamaan, saling menghormati, toleransi, inklusifisme, kerukunan antar umat beragama melalui pendidikan merupakan cara yang efektif dan tepat. Hal ini dikarenakan bahwa sesuatu yang ditanamkan pada anak akan menjadi "mindset" cara berfikir bahkan cara pandang hidup akan sulit untuk hilang dan pudar. Pemerintah sudah selayaknya memberikan perhatian yang lebih besar dalam upaya penanaman nilai-nilai tersebut, khususnya melalui jenjang pendidikan. Jenjang pendidikan yang dimaksudkan tidak hanya pada jenjang pendidikan tinggi, namun akan lebih maksimal manakala sudah dimulai sejak usia dini.

Saat ini isu agama di Indonesia marak terjadi, bahkan digunakan oleh pihak-pihak yang tidak bertanggung jawab untuk menjatuhkan pihak lain .Konflik berbau agama, jauh sebelum baru-baru ini terjadi, sudah meletup sejak dulu di berbagai tempat di Indonesia. Radikalisme agama tumbuh subur di negeri ini. Menurut Tien Rohmatin tahun 2016 aksi kekerasan berbasis agama kerap terjadi dan bahkan intensitasnya makin meningkat dewasa ini. Hal ini makin memerlihatkan bahwa wacana pluralisme dan kebebasan agama masih menjadi problem krusial bagi kehidupan sosial-keagamaan di Indonesia seperti tampak dari "Laporan Tahunan Kehidupan Beragama di Indonesia 2009" yang dikeluarkan oleh Center for Religious and Cross-Cultural Studies (CRCS) UGM Yogyakarta. Hal ini khususnya terkait pertentangan dalam pendirian rumah ibadah, wacana penyesatan dan penyerangan terhadap kelompok minoritas agama diluar paham keyakinan yang mainstream. Peningkatan praktik intoleransi terlihat dari pantauan Setara Institute. Pada 2007, lembaga ini mencatat, terjadi 135 peristiwa pelanggaran dengan 185 tindakan pelanggaran; pada 2008 terjadi 265 peristiwa pelanggaran dengan 367 tindakan pelanggaran; pada 2009 terjadi 200 peristiwa pelanggaran dengan 291 tindakan pelanggaran; dan pada 2010 terjadi 216 peristiwa pelanggaran dengan 286 tindakan pelanggaran. Bahkan data lainnya menunjukkan dari 491 pelanggaran yang dilaporkan di tahun 2009, meningkat menjadi 543 di tahun 2011. Target utama dari aksi intoleransi ini adalah kelompok minoritas, seperti umat Kristiani, Ahmadiyah, dan kaum Syīaah. Data juga menunjukkan eskalasi penyerangan terhadap rumah ibadah, khususnya terhadap umat Kristiani terus meningkat dari tahun ke tahun. Setara Institute mencatat pada tahun 2008 terdapat 17 tindakan; pada tahun 2009 terdapat 18 tindakan pelanggaran; dan pada tahun 2010 sejak Juni-Juli tercatat 28 peristiwa pelanggaran kebebasan beragama dan berkeyakinan. 
Menurut pendapat Scholastica Gerintya tahun 2018 bahwasanya pada tahun 2017 telah terdapat 155 pelanggaran kebebasan beragama/berkeyakinan tercatat dengan 201 bentuk tindakan. Sebanyak 75 tindakan pelanggaran melibatkan aktor negara, yaitu 71 berbentuk tindakan aktif, 3 tindakan by rule, sementara 1 tindakan lainnya merupakan tindakan pembiaran. Sebanyak 126 tindakan dilakukan oleh aktor non-negara dengan pelaku tertinggi adalah kelompok warga, yakni 28 tindakan. Hal ini menunjukkan bahwa semua golongan warga Negara Indonesia ikut berpartisipasi dalam terjadinya kasus pelanggaran bernuansa agama. Berdasarkan hasil penelitian Nazar Nurdin tahun 2018 dari Lembaga Studi Sosial dan Agama ( eLSA) Semarang, di Jawa Tengah ada 29 kasus menonjol berkaitan dengan agama yang disorot selama tahun 2018. Jumlah tersebut meningkat dibanding periode sama tahun 2017 yang hanya ada puluhan kasus pelanggaran. Namun seperti tahun sebelumnya, mayoritas pelanggaran yang terjadi masih didominasi penolakan terhadap kegiatan berbasis agama. Tindakan intoleransi berkutat pada kasus bernuansa agama, pendirian rumah ibadah, dan konflik horizontal pada masyarakat.

Survei Wahid Foundation tahun 2016 menemukan sejumlah data yang dinilai cukup mengkhawatirkan. Dari total 1.520 responden, sebanyak 59,9 persen memiliki kelompok yang dibenci. Kelompok yang dibenci meliputi mereka yang berlatarbelakang agama nonmuslim, kelompok tionghoa, komunis, dan lainnya. Dari jumlah 59,9 persen itu, sebanyak 92,2 persen tak setuju bila anggota kelompok yang mereka benci menjadi pejabat pemerintah di Indonesia. Sebanyak 82,4 persennya bahkan tak rela anggota kelompok yang dibenci itu menjadi tetangga mereka.

Dari sisi radikalisme sebanyak 72 persen umat Islam Indonesia menolak untuk berbuat radikal seperti melakukan penyerangan terhadap rumah ibadah pemeluk agama lain atau melakukan sweeping tempat yang dianggap bertentangan dengan syariat Islam . Dan hanya sebanyak 7,7 persen yang bersedia melakukan tindakan radikal bila ada kesempatan dan sebanyak 0,4 persen justru pernah melakukan tindakan radikal. Kendati demikian, kata Direktur Wahid Foundation Yenny Wahid Yenny, ada temuan positif dalam survei kali ini. Sebanyak 67,3 persen mendukung pemberlakuan sistem demokrasi di Indonesia dan 82,3 persen menyatakan dukungannya kepada Pancasila dan UUD 1945. Dia mengatakan penyebab terjadinya intoleransi dan radikalisme di tubuh umat Islam Indonesia selain ideologi ialah alienasi dalam sektor sosial dan ekonomi.

Kota Solo banyak dihubung-hubungkan dengan aksi terorisme dan bahkan sering disebut sebagai sarang teroris. Menurut Arasy tahun 2011 Direktur Deradikalisasi BNPT, Irfan Idris yang mengungkapkan bahwa mahasiswa di Solo sudah banyak yang dibina teroris melalui gerakan radikal dengan pintu masuk organisasi dakwah . Oleh karena itu tidak heran apabila di wilayah Solo sediri banyak kasus yang berkaitan dengan aksi terorisme. Banyak pelaku anggota jaringan teroris yang tertangkap dan bahkan terbunuh dalam penyerangan di Solo. Di antaranya adalah gembong teroris Noordin M. Top beserta tiga teroris lainnya (Ario Sudarso alias Suparjo Dwi Anggoro alias Aji alias Dayat alias Mistam Husamudin, Adib alias Susilo dan Urwah alias Bagus Budi Pranoto) pada 17 September 2009. Noordin M. Top tewas setelah pengepungan dan aksi baku tembak yang terjadi di Kampung Kepuhsari, Mojosongo, Jebres, Solo. Pada 13 Mei 2010 Densus 88 menggerebek sebuah bengkel yang 
digunakan sebagai sarang teroris di Dusun Gondang, RT 03/ RW 06, Desa Bakipandean, Kecamatan Baki, Sukoharjo. Pada 14 Mei 2011 polisi juga telah menembak mati Sigit Qardhawi (Amir Tim Hisbah) dan Hendro di Jalan Pelajar Pejuang, Kecamatan Cemani, Sukoharjo dan menangkap Edi T. alias Edi Jablay, Ari Budi alias Abas alias Irwan, Hari Budiarto alias Nobita dan Aripin Haryono yang diduga mengetahui dan terlibat dalam kasus Bom Cirebon. Pada 25 September 2011 terjadi aksi terorisme di Gereja Bethel Injil Sepenuh (GBIS) Kepunton, Jalan Arif Rachman Hakim, Solo yang merupakan bom bunuh diri. Sedangkan berita terbaru yaitu pada bulan Agustus 2019 penangkapan teroris bernama Abdul Rochim oleh Densus 88 di Mojosongo, ia merupakan warga Banjarsari yang ditangkap saat dalam perjalanan menuju Sragen untuk menghadiri hajatan kerabat. Beberapa contoh kasus terorisme di Solo tersebut dapat menunjukkan bahwa Solo merupakan wilayah yang memiliki potensi besar terhadap ancaman aksi terorisme.

Faktor terjadinya intoleran dalam hal agama dikarenakan kurangnya pemahaman masyarakat tentang ilmu keagamaan. Perlu diketahui bahwasanya semua agama mengajarkan kepada umatnya untuk saling menjaga kerukunan dan toleransi. Penanaman sikap toleransi kepada umat beragama sangat penting dipupuk sejak dini. Penanaman sikap toleransi bisa dilakukan oleh siapa saja baik lembaga formal maupun informal. Bagi anak yang kurang beruntung didalam keluarganya, baik sebagai yatim, piatu atau berasal dari keluarga yang kurang mampu demi menunjang pendidikannya akan dititipkan pada panti asuhan. Anakanak di panti asuhan dapat dibina kepribadiannya dengan jalan menghindarkan anak dari sifat-sifat suka mencuri, berbohong, berkelahi dll. Pembina atau pengasuh panti asuhan memiliki tanggung jawab untuk membina serta memelihara anak asuhnya secara wajar dan penuh kasih sayang.

Salah satu panti asuhan yang berada di Surakarta yang menjadi penelitian yaitu LKSA Nur Hidayah. Perlu diketahui bahwasanya LKSA Nur Hidayah merupakan panti yang berbasis agama Islam dan hidup di tengah-tengah warga, tidak dapat dipungkiri bahwa LKSA Nur Hidayah hidup diantara perbedaan yang ada di masyarakat.

Beberapa penelitian menjelaskan toleransi agama dalam perspektif umum dan objek penelitian merupakan instansi yang inklusif. Melihat kenyataan bahwa Indonesia sering kali mengalami permasalahan terkait toleransi agama, maka peneliti tertarik untuk melakukan penelitian tentang toleransi agama dalam perspektif agama Islam yaitu bagaimana pola pembentukan pada perilaku toleransi beragama pada anak yang dilakukan oleh LKSA Nur Hidayah.

\section{METODE PENELITIAN}

Penelitian dilakukan di LKSA Nur Hidayah tepatnya di Jl. Pisang No 12 Rt 02 Rw 13, Laweyan, Surakarta. LKSA Nur Hidayah merupakan panti asuhan yang mengasuh anak dari berbagai daerah dan saat ini sudah memiliki 6 asrama dan tersebar di solo dan boyolali.

Penelitian ini menggunakan jenis penelitian kualitatif dengan pendekatan studi kasus. Studi kasus merupakan penelitian yang mempelajari secara intensifitas mendalam satu anggota dari kelompok sasaran suatu subjek penelitian (Silalahi, 2012). Dalam strategi ini, peneliti menyelidiki secara cermat suatu program, peristiwa, aktivitas, proses, atau 
sekelompok individu. Peneliti mengumpulkan informasi maupun data secara lengkap dengan menggunakan berbagai prosedur pengumpulan data berdasarkan waktu yang telah ditentukan. Peneliti menggunakan pendekatan studi kasus untuk mengetahui lebih jelas aktivitas didalam LKSA Nur Hidayah dalam memberikan pembinaan LKSA Nur Hidayah dalam membentuk perilaku toleransi pada anak pada jenjang SD,SMP,SMA di kalangan masyarakat. Adapun dalam penelitian ini peneliti menggunakan tipe observasi tidak berpartisipasi. Teknik pengambilan sampel adalah purposive sampling. Teknik wawancara yang digunakan dalam penelitian ini adalah teknik wawacara secara mendalam terhadap beberapa subjek yang telah ditentukan terlebih dahulu. Peneliti boleh saja mengajukan pertanyaan secara meloncat-loncat dari waktu kewaktu, atau dari topik yang satu ke topik yang lainnya (Slamet, 2006).

Peneliti melakukan wawancara dengan beberapa pengurus LKSA Nur Hidayah yang melakukan pembinaan pada anak didik. Selain itu peneliti juga melakukan wawancara dengan anak didik LKSA Nur Hidayah selaku penerima pembinaan dari pengurus LKSA Nur Hidayah serta masyarakat di sekitar LKSA Nur Hidayah untuk mengetahui toleransi sosial dan agama di kalangan masyarakat. Untuk menguji validitas data dilakukan triangulasi sumber membandingkan jawaban informan lain dalam mengkroscek data yang diperoleh langsung sehingga data yang satu terkontrol oleh data lain. Teknik analisis menggunakan model analisis interaktif dari Miles \& Hubermas yang terdiri dari tiga skema secara bersamaan yaitu reduksi data, penyajian data, penarikan kesimpulan.

\section{HASIL DAN PEMBAHASAN}

Berdasarkan hasil penelitian yang dilakukan peneliti di LKSA Nur Hidayah telah memberikan pembinaan untuk membentuk perilaku toleransi pada anak dikalangan masyarakat yang dimasukkan dalam kajian setiap 2 kali dalam seminggu dan dalam kehidupan sehari-hari.

a. Kedamaian

LKSA Nur Hidayah terletak di tengah perkampungan warga di daerah Kerten. Warga sering bersosialisasi satu sama lainnya sebagai warga kampung, karena hakikatnya manusia adalah makhluk sosial. oleh karena itu LKSA Nur Hidayah berusaha mewujudkan kedamaian agar tercipta kehidupan yang baik antara anak asuh dan warga sekitar. Untuk membentuk kedamaian tidak hanya dilakukan dengan bertegur sapa dan melayat di rumah warga sekitar namun juga pengasuh dan anak asuh sholat berjamaah dimasjid setempat untuk dapat membaur dengan masyarakat sekitar.

b. Terbuka dan menerima keindahan perbedaan

LKSA Nur Hidayah mengajarkan anak asuh untuk terbuka dan menerima perbedaan yang terjadi di tengah masyarakat. Wujud implementasi dari sikap terbuka yaitu anak asuh di bebaskan untuk bergaul dengan siapapun tidak terkecuali dengan teman yang berbeda keyakinan. Namun pengasuh tetap memberikan himbauan agar anak tidak larut mengikuti arus keyakinan orang lain. Kemudian pengasuh di LKSA Nur Hidayah juga mengajarkan anak asuh untuk melaksanakan sholat berjamaah di masjid dekat panti. Sholat berjamaah tersebut dimaksudkan supaya anak dapat membaur dengan warga dan tidak terkesan 
menutup diri. Sholat berjamaah dijadwalkan pada hari minggu yang kemudian setelah sholat berjamaah dilanjutkan dengan les mata pelajaran. Namun kebijakan setiap panti berbeda dalam hal sholat berjama'ah di masjid, jika panti putri menjadwalkan anak asuhnya untuk sholat berjama'ah pada hari minggu,berebda dengan wisma putri yang mengharuskan anak asuhnya untuk sholat berjama'ah setiap hari di masjid. Ada sebuah fakta bahwa di belakang kantor dan panti putra Nur Hidayah berdiri sebuah Gereja Kristen Jawa (GKJ) yang berdiri jauh sebelum LKSA Nur Hidayah ada. Keduanya hidup harmonis selama puluhan tahun. Dibangunnya yayasan Nur Hidayah di belakang Gereja dapat berarti siap untuk menerima perbedaan. Meskipun Selama ini belum pernah terlihat kebersamaan antara GKJ dengan Nur Hidayah namun keduanya menjalin hubungan yang sangat baik.

c. Penghargaan timbal balik lewat pemahaman yang juga timbal balik

Penghargaan dalam penelitian ini diberikan oleh anak-anak murid yang berada di LKSA Nur Hidayah dengan para pengasuh karena telah mendapatkan sebuah pembelajaran sebagai bekal mereka untuk masa depan, dan kemudian anak murid yang berada disana juga memberikan timbal balik dengan cara berbakti kepada Pembina atau pun pengasuh dan belajar dengan serius sesuai dengan kemampuan nya. Pengasuh panti sebagai pengganti orang tua anak asuh berusaha keras bisa menjadi yang di harapkan oleh mereka. Tidak mudah melakukannya karena menghadapi anak yang sudah besar disamping itu pengasuh baru memiliki anak yang masih balita. Tapi hal tersebut bukan sebuah hambatan bagi pengasuh dan saat ini anak-anak sudah menganggap pengasuh adalah pengganti orang tuanya. Dalam memberikan ilmu baik agama maupun umum pengasuh memiliki cara tersendiri agar anak mudah memahami apa yang ia sampaikan. Pak Dona lebih senang memberikan praktik, dan penggunaan bahasa yang mudah dimengereti dalam memberikan ilmu pada anak asuhnya. Hal tersebut dikarenakan tidak semua anak memiliki kapasitas pemahaman yang sama sehingga apabila praktik di lakukan itu akan mudah diingat oleh anak-anak. Dalam membentuk perilaku anak, hampir semua pembinaan yang dilaksanakan oleh LKSA Nur Hidayah tidak membedakan antara anak asuh yang duduk di bangku Sekolah Dasar (SD) dengan yang sudah duduk di bangku Sekolah Menengah Pertama (SMP), dan Sekolah Menengah Atas (SMA). Beberapa pembinaan yang tidak membedakan jenjang umur anak asuh diantaranya kajian bersama Ustad Dede. Hal tersebut dilakukan untuk mempersingkat waktu dan tema yang diberikan bisa diterima semua umur. Selain itu dalam pelaksanaan masalah ibadah, pengasuh tidak membedakan antara anak yang masih kecil dan yang sudah besar. Apabila waktu sholat, kajian, dan kegiatan lainnya anak harus mengikuti. Apabila kajian yang diberikan mengenai permasalahan seperti seksualitas maka anak asuh yang masih SD tidak mengikuti kajian tersebut. Kajian semacam ini waktu pelaksanaan tidak menentu dan tergantung dengan topik yang sedang hangat dibicarakan.

d. Benih-benih intoleransi adalah ketakutan dan keacuhan

Pada penelitian kali ini, warga yang merupakan kaum nasrani tidak mempermasalahkan dan menerima perbedaan yang ada meskipun hidup diantara masyarakat muslim. Salah satu narsumber dan memiliki keyakinan Kristen yaitu pak Darmanto. Selaku 
ketua RT pak darmanto harus bisa mengayomi warganya supaya tidak ada permasalahan yang membuat perpecahan. Saat wawancara berlangsung tidak terlihat raut wajah ketakutan dan jawabannya menerangkan bahwa apabila pihak LKSA mengadakan pengajian maka akan memberitahu terlebih dahulu karena pasti akan ramai-ramai. Jadi komunikasi antara pihak LKSA Nur Hidayah dengan warga cukup lancar. Pendidikan warga yang cukup baik dan berasal dari berbagai profesi membuat daerah di sekitar tempat tinggal panti LKSA Nur Hidayah tidak terjadi permasalahan yang menyangkut agama. Kehidupan yang nyaman dan tenteram sehingga dapat memunculkan sikap toleransi yang yang baik adalah saling peduli satu sama lain. Dalam penelitian ini peneliti tidak menemukan sikap keacuhan yang ada dalam diri LKSA Nur Hidayah dengan warga begitu juga sebaliknya. Masyarakat dan LKSA Nur Hidayah hidup berdampingan dengan baik.

e. Benih-benih toleransi cinta, diairi oleh kasih sayang dan perhatian

Perhatian merupakan wujud dari cinta itu sendiri. Apabila cinta dan perhatian tidak ada didunia ini maka bisa jadi keseimbangan hidup akan terganggu. Cinta yang diairi oleh kasih sayang dan perhatian dapat membentuk karakter seseorang. LKSA Nur Hidayah memberikan kasih sayang dan perhatian kepada anak asuhnya secara penuh, untuk membentuk sikap pada anak tersebut LKSA Nur Hidayah melalui pengasuh memberikan kajian mengenai kehidupan yang baik dan benar sesuai dengan tuntunan agama serta sesuai dengan norma yang ada di masyarakat. Terkait dengan penelitian cinta yang diberikan oleh pengasuh terhadap anak asuh yaitu memberikan pengetahuan mengenai kehidupan bermasyarakat yang hidup diantara perbedaan. Dijelaskan oleh pengasuh yang memberikan kajian bahwasanya dalam bermasyarakat kita tetap dibolehkan berhubungan untuk menjaga silaturahmi antara umat manusia meski memiliki perbedaan agama. Dalam penelitian ini anak asuh di LKSA Nur Hidayah diajarkan untuk dapat berbaur dengan masyarakat, hal yang diajarkan oleh LKSA Nur Hidayah yaitu melayat kerumah tetangga yang sedang dirundung kesedihan ditinggal anggota keluarga untuk selamanya. Selain itu biasanya setiap menuju hari raya idul fitri LKSA Nur Hidayah mengadakan bakti sosial (baksos) yang ditunjukan untuk masyarakat sekitar yang kurang mampu. Anak-anak di LKSA Nur Hidayah sudah merasa saling memiliki dan mengasihi, hal tersebut dikarenakan mereka hidup bersama dalam satu atap dan tidur di satu ruangan bersama.

\section{f. Menghargai kebaikan orang lain dan situasi-situasi}

Dalam penelitian ini menghargai yang diajarkan oleh pihak LKSA Nur Hidayah kepada anak asuhnya yaitu menghargai donatur yang telah memberikan sumbangan ke LKSA Nur Hidayah. Sumbangan tersebut dapat berupa makanan yang diantarkan ke LKSA Nur Hidayah atau anak asuh diajak pergi ke suatu tempat untuk menghadiri acara yang telah di buat oleh donatur, selain itu donatur dapat memberikan donasi berupa uang tunai yang dapat diserahkan ke kantor sekretariat LKSA Nur Hidayah atau transfer. Sebagai bentuk rasa terimakasih dan rasa menghargai bagi donatur setiap selepas magrib para anak asuh mendoakan donatur-donatur yang telah memberikan sumbangannya. Doa dipimpin oleh pengasuh di masing-masing panti. 
g. Menghargai individualitas dan perbedaan

Menghargai memiliki arti yang luas yaitu menghormati, menilai, tidak merendahkan apabila diambil dalam konteks agama menghargai dapat diartikan tidak menganggu ibadah orang lain. Hal tersebut bertujuan untuk terciptanya kerukunan antar umat manusia seperti pada penjelasan sebelumnya. Menurut Kamus Besar Bahasa Indonesia individualitas memiliki arti keadaan atau sifat khusus sebagai individu, ciri-ciri yang membedakan antara satu orang dengan orang lain yaitu watak kepribadian. Watak merupakan sifat manusia yang mempengaruhi tingkah laku. Individu satu dengan individu yang lainnya tidaklah sama, oleh karenanya dibutuhkan sikap untuk saling menerima perbedaan satu sama lain sambil menghilangkan topeng-topeng pemecah belah. Dalam penelitian kali ini anak asuh di LKSA Nur Hidayah diajarkan untuk selalu menhormati, menghargai orang lain walaupun memiliki perbedaan.

h. Mentolerir ketidaknyamanan hidup

Salah satu butir toleransi adalah mentolerir ketidaknyamanan. Mentolerir sama halnya dengan menerima, tidak dipungkiri bahwa dalam kehidupan pasti pernah mengalami hal yang tidak mengenakan. Namun hal tersebut dapat diterima baik dari LKSA Nur Hidayah maupun masyarakat. Dalam kenyataannya tidak pernah terjadi permasalahan yang berarti antara LKSA Nur Hidayah dengan masyarakat. Apabila LKSA Nur Hidayah sedang mengadakan acara biasanya memberitahukan oleh RT setempat sebagai bentuk pemberitahuan.

Tabel 1. Kesimpulan Hasil Penelitian

\begin{tabular}{|c|c|c|c|}
\hline \multirow{2}{*}{ No } & \multirow{2}{*}{ Sikap } & \multicolumn{2}{|c|}{ Keterangan } \\
\hline & & LKSA & Masyarakat \\
\hline 1 & Kedamaian & $\begin{array}{l}\text { - Tertegur sapa dengan masyarakat } \\
\text { - Melayar dirumah warga } \\
\text { - Shalat berjamaah di masjid }\end{array}$ & $\begin{array}{l}\text { - Bertegur sapa } \\
\text { - Mengundang pengajian ke } \\
\text { masjid }\end{array}$ \\
\hline 2 & $\begin{array}{l}\text { Tebuka dan } \\
\text { menerima } \\
\text { keindahan } \\
\text { perbedaan }\end{array}$ & $\begin{array}{l}\text { - Memberikan kebebasan untuk } \\
\text { bergaulnamun tetap ada batasan } \\
\text { - Tidak menyinggung agama lain } \\
\text { - Tidak menggangu ibadah } \\
\text { - Ikut lomba 17an } \\
\text { - Mengundang tokoh masyarakat } \\
\text { dalam acara ulang tahun Nur } \\
\text { Hidayah }\end{array}$ & $\begin{array}{l}\text { - Mengajak kerja bakti } \\
\text { untukmembersihkan } \\
\text { lingkungan sekitar } \\
\text { - Gereja menyelengarakan } \\
\text { jalan sehat untuk umum }\end{array}$ \\
\hline 3 & $\begin{array}{l}\text { Penghargaan } \\
\text { timbal balik } \\
\text { lewat } \\
\text { pemahaman } \\
\text { yang juga } \\
\text { timbal balik }\end{array}$ & $\begin{array}{l}\text { - Memberikan materi mengunakan } \\
\text { bahasa yang dimengerti oleh } \\
\text { anak-anak } \\
\text { - Mengajarkan anak tentang skil } \\
\text { memasak } \\
\text { - Mengajarkan bertegur sapa kepada } \\
\text { orang yang lebih tua } \\
\text { - Memberi sanksi apabila anak }\end{array}$ & $\begin{array}{l}\text { - Apa bila anak panti menyapa } \\
\text { akan dibalas dengan sapaan } \\
\text { - Pengurus diberikan uang } \\
\text { - Warga terbuka dengan anak- } \\
\text { anak dari LKSA Nur } \\
\text { Hidayah }\end{array}$ \\
\hline
\end{tabular}




\begin{tabular}{|c|c|c|c|}
\hline & & $\begin{array}{l}\text { melanggar aturan disesuaikan } \\
\text { dengan umur anak }\end{array}$ & \\
\hline 4 & $\begin{array}{l}\text { Butir -butir } \\
\text { intoleransi } \\
\text { adalah } \\
\text { ketakutan } \\
\text { keacuhan }\end{array}$ & $\begin{array}{l}\text { - Tidak mepermasalahkan gereja } \\
\text { dibelakan kantor Nur Hidayat } \\
\text { - Menerima perbedaan dang } \\
\text { mengajarkan bermasyarakat harus } \\
\text { tetap memenuhi hak tetangga } \\
\text { meskipun berbeda agama }\end{array}$ & $\begin{array}{l}\text { - Diberi tahu apabila LKSA } \\
\text { mengadakan acara }\end{array}$ \\
\hline 5 & $\begin{array}{l}\text { Butir -butir } \\
\text { toleransi, } \\
\text { cinta dari } \\
\text { oleh kasih } \\
\text { sayang dan } \\
\text { perhatian }\end{array}$ & $\begin{array}{l}\text { - } \begin{array}{l}\text { Memberikan pengetahuan } \\
\text { mengenai kehidupan }\end{array} \\
\text { bermasyarakat yang hidup diantara } \\
\text { perbedaan } \\
\text { - Membina anak untuk berbagi } \\
\text { - Menyayangi sesama penghuni } \\
\text { panti } \\
\text { - Mengadakan bakti sosial untuk } \\
\text { masyarakat menjelan idul fitri } \\
\text { - Memberikan kupon daging pada } \\
\text { masyarakat pada saat idul adha }\end{array}$ & \\
\hline 6 & $\begin{array}{l}\text { Menghargai } \\
\text { kebaikan } \\
\text { orang lain } \\
\text { dan situasi- } \\
\text { situasi }\end{array}$ & $\begin{array}{l}\text { - Menghargai donatur yang telah } \\
\text { memberikan bantuan }\end{array}$ & \\
\hline 7 & $\begin{array}{l}\text { Menghargai } \\
\text { individualitas } \\
\text { dan } \\
\text { perbedaan }\end{array}$ & $\begin{array}{l}\text { - Menghargai dan menghormati } \\
\text { perbedaan } \\
\text { - Tidak mengolok-olok orang lain } \\
\text { - Saling bertegur sapa }\end{array}$ & $\begin{array}{l}\text { - Menjaga hubungan harmonis } \\
\text { antara gereja dan Nur } \\
\text { Hidayah } \\
\text { - Saling bertegur sapa }\end{array}$ \\
\hline 8 & $\begin{array}{l}\text { Mentoleransi } \\
\text { ketidak } \\
\text { nyamanan } \\
\text { hidup }\end{array}$ & $\begin{array}{l}\text { - Memberi tahu warga apabila ada } \\
\text { acara }\end{array}$ & $\begin{array}{l}\text { - Mengajak anak untuk kerja } \\
\text { bakti }\end{array}$ \\
\hline
\end{tabular}

Perlu diketahui bahwa letak LKSA Nur Hidayah berdekatan dengan 2 gereja yaitu Gereja Katolik Santo Paulus dan Gereja Kristen Jawa. Kedua Gereja sudah berdiri jauh sebelum LKSA berkembang. Gereja Katolik Santo Paulus yang beralamat di Jl. Belimbing No 18 berdiri sejak tahun 1980 dan saat ini sudah berdiri kokoh dan merupakan gereja yang cukup besar. Kemudian Gereja Kristen Jawa Kerten yang beralamat di J1. Siwalan No 42 Kerten. Kantor Yayasan Nur Hidayah dan panti putra LKSA Nur Hidayah berada di belakang persis Gereja Kristen Jawa. Lalu masjid yang dipergunakan anak panti di LKSA Nur Hidayah berdekatan dengan Gereja Katolik Santo Paulus sering kali menjelang sholat magrib atau sesudah sholat subuh membunyikan lonceng sebagai tanda peribadatan akan dimulai.

Hal tersebut membuktikan bahwa di daerah LKSA Nur Hidayah kerukunan antar agama dapat terjaga, karena selama ini tidak pernah ada masalah yang menyangkut keagamaan. Puluhan tahun warga dapat menjaga keharmonisan dalam toleransi beragama, meskipun mayoritas warga setempat menganut agama Islam. Warga yang berasal dari 
berbagai kalangan dan dianggap memiliki pendidikan yang cukup baik sehingga memiliki pemikiran yang dewasa dan dapat menerima suatu perbedaan yang ada di masyarakat. pengasuh dan anak asuh tidak mempermasalahkan adanya gereja-gereja tersebut asalkan dipergunakan baik oleh masyarakat setempat. Mereka menyadari bahwa memang dalam kehidupan bermasyarakat terdapat perbedaan-perbedaan. Apabila tidak saling menganggu toleransi beragama dapat terjaga dengan baik.

Menggunakan teori praktik sosial dari Bourdieu habitus terbentuk melalui pembinaan yang diberikan dengan cara memberikan pengertian pada anak pentingnya bertoleransi dengan sesama umat manusia walaupun memiliki latar belakang agama yang berbeda. Pengertian yang diberikan oleh pihak LKSA Nur Hidayah dengan cara memberikan sosialisasi pada saat kajian rutin selama $2 \mathrm{x}$ dalam satu minggu. Tema yang diberikan pengasuh pada saat kajian bisa sesuai permintaan atau request tetapi juga terkadang pengasuh memilihkan sendiri tema yang akan di sampaikan. LKSA Nur Hidayah memilih 4 cabang panti di Surakarta 3 di wilayah Kerten dan 1 di wilayah Banjarsari. pengasuh bernama Ustad Dede memberikan kajian setiap 2 kali dalam satu minggu di keempat panti tersebut secara bergantian. Untuk panti putri dan wisma putri Ustad Dede di gabung menjadi satu karena letak yang berdekatan. Selain pemberian pemahaman melalui kajian yang di berikan Ustad Dede ,pengasuh masing-masing panti juga memberikan kajian dan pemahaman, waktu yang digunakan pengasuh panti memberikan pemahaman pada anak asuh cenderung fleksibel, biasanya pada saat ba'da magrib anak asuh dikumpulkan untuk mengaji bersama dan tidak jarang diselipkan pemahaman mengenai kehidupan sosial dan agama hal demikian berlangsung setiap hari. LKSA Nur Hidayah juga mengajarkan anak untuk tidak menganggu agama lain untuk menghargai individualitas dan perbedaan. Untuk menciptakan kedamaian anak asuh diwajibkan untuk sholat berjama'ah di masjid, dengan begitu masyarakat mengenali dan bisa membaur dengan anak panti. Benih-benih intoleransi yaitu ketakutan dan keacuhan apabila hal tersebut dikembangkan maka toleransi beragama sulit terwujud. Untuk menghindari intoleransi LKSA Nur Hidayah mengajarkan pada anak bahwa dalam bermasyarakat tidak boleh membeda-bedakan hak tetangga harus tetap diberikan sekalipun berbeda keyakinan. LKSA Nur Hidayah mengajarkan anak sifat terbuka dan menerima keindahan perbedaan, yaitu dengan bertegur sapa dengan masyarakat apabila bertemu di jalan, dan menanamkan rasa saling menghormati satu sama lain.

Pada kaitanya dengan penelitian, peneliti menggunakan beberapa modal dalam teori praktik sosial yaitu modal sosial,modal budaya dan modal simbolik dan modal ekonomi. Modal sosial memiliki 3 unsur yaitu jaringan, kepercayaan dan norma. Modal sosial dapat dilihat melalui membagikan kupon daging kurban pada saat Idul Adha kepada masyarakat sekitar Yayasan Nur Hidayah. Pembagian kupon masuk dalam sikap butir-butir toleransi ,cinta yang diairi oleh kasih sayang dan perhatian. Perhatian tidak hanya pada sesama penghuni panti namun juga dengan masyarakat sekitar. Selain memberikan kupon pengambilan daging kurban, LKSA Nur Hidayah juga mengadakan bakti sosial yang biasanya dilaksanakan menjelang Idul Fitri. Letak LKSA Nur Hidayah yang berada ditengah perkampungan warga memungkinkan terjadi interaksi dengan masyarakat sekitar, bakti sosial juga termasuk dalam sikap benih-benih toleransi cinta, diairi oleh kasih sayang dan perhatian. 
Dalam unsur modal sosial pembagian kupon daging kurban Idul Adha dan bakti sosial yang dilaksanakan menjelang Idul fitri termasuk dalam jaringan, karena membangun hubungan antara LKSA Nur Hidayah dengan masyarakat dan dapat memberikan manfaat dalam hubungan tersebut.

Untuk membentuk kedamaian antara LKSA Nur Hidayah dengan masyarakat, salah satu upaya yang dilakukan adalah apabila ada tetangga yang meninggal maka pengurus akan takziah ke rumah warga tersebut. Upaya yang dilakukan oleh LKSA Nur Hidayah sudah selayaknya dilakukan, karena mereka hidup diantara masyarakat setempat. LKSA Nur Hidayah telah melaksanakan norma kesopanan,dimana mereka melakukan tindakan yang sudah menjadi kebiasaan dan kepatutan yang ada di masyarakat, ketika ada tetangga yang sedang menerima musibah atau ada tetangga yang meninggal maka akan takziah. Kemudian ketika hendak mengadakan acara besar, sikap mentolerir kenyamanan hidup yang ditunjukan oleh pihak LKSA Nur Hidayah yaitu meminta izin pada ketua RT setempat karena letak di tengah perkampungan dan dilalui oleh jalan utama menuju jalan besar dari warga setempat. Sama seperti takziah, meminta izin sebelum mengadakan acara besar termasuk dalam norma kesponan. Hal demikian sudah sepantasnya dilakukan oleh LKSA Nur Hidayah, untuk menghindari hal-hal yang tidak diinginkan pihak LKSA Nur Hidayah mengurus perizinan terlebih dahulu pada Ketua RT.

LKSA Nur Hidayah terbuka dan menerima keindahan perbedaan, LKSA Nur Hidayah mengajarkan anak asuhnya untuk terbuka dan menerima perbedaan. Anak-anak di LKSA Nur Hidayah diberikan kebebasan dalam bergaul,namun tetap di berikan batasanbatasan dalam bergaul, menjaga aqidah diri sendiri merupakan hal penting dalam bergaul dengan orang yang memiliki latar belakang keyakinan yang berbeda. Gereja Kristen Jawa (GKJ) pernah mengadakan jalan sehat yang terbuka untuk umum, beberapa staff dan anak asuh dan masyarakat mengikuti acara tersebut. LKSA Nur Hidayah turut mengundang tokoh masyarakat dalam acara milad Nur Hidayah, untuk menjaga tali silaturahmi dengan masyarakat. Nur Hidayah memiliki sebuah poliklinik, poliklinik tersebut terkadang diminta masyarakat untuk membantu mensukseskan kegiatan yang diselenggarakan oleh masyarakat. dari uraian tersebut terdapat hubungan yang dibangun antara LKSA Nur Hidayah dan masyarakat dan memberikan manfaat yang dirasakan,dalam modal sosial termasuk dengan jaringan. Namun tanpa kepercayaan antara kedua belah pihak, hubungan yang terjalin keduanya tidak akan terwujud dengan baik. Kepercayaan juga menjadi point penting dalam menjaga toleransi beragama di kalangan masyarakat. Kepercayaan dapat hilang begitu saja apabila terdapat gejolak atau konflik diantara kedua belah pihak.

LKSA Nur Hidayah berada di lingkungan perkampungan di wilayah Kerten dan Banjarsari,hal tersebut memungkinkan terjadinya interkasi dengan masyarakat sekitar baik dengan anak atau dengan pengasuh panti. LKSA Nur Hidayah sebagai pengganti keluarga bagi anak asuhnya tidak hanya memberikan pemahaman mengenai kehidupan beragama melainkan juga kehidupan sosial, karena pada dasarnya manusia itu adalah makhluk sosial. Anak asuh di LKSA Nur Hidayah diajarkan untuk saling tolong menolong,gotong royong dalam masyarakat, mengikuti lomba 17-an dan dibebaskan untuk bermuamalah baik dengan sesama muslim maupun non muslim hal demikian termasuk dengan modal budaya. 
Modal simbolik dalam penelitian ini yaitu Pengasuh LKSA Nur Hidayah menilai jika toleransi yang terjalin diantara LKSA Nur Hidayah selama ini dikarenakan masyarakat setempat memiliki latar belakang pekerjaan yang berbeda-beda dengan pendidikan yang cukup baik. Sehingga masyarakat memiliki pemikiran yang modern, dan dapat menerima perbedaan satu sama lain. Masyarakat setempat juga menilai jika anak-anak di LKSA Nur Hidayah memiliki kelakuan yang baik, dan tidak membuat gaduh di lingkungan masyarakat setempat, LKSA Nur Hidayah dinilai dapat mencetak anak-anak dengan budi pekerti yang bagus.

LKSA Nur Hidayah bukan tidak mungkin dalam melaksanakan pembinaannya tidak mengeluarkan ongkos atau biaya untuk membayar keperluan yang dibutuhkan oleh anakanak. LKSA Nur Hidayah berkewajiban untuk membayar pengasuh baik pengasuh panti maupun pengasuh yang memberikan kajian setiap minggunya. Kemudian LKSA Nur Hidayah wajib memberikan uang saku yang berkaitan dengan sekolah dan wajib membiayai sekolah anak asuh dari jenjang SD, SMP, SMA selama anak tersebut menjadi bagian dari LKSA Nur Hidayah. Sikap terbuka juga ada dalam modal ekonomi yaitu mengadakan bakti sosial yang diperuntukan untuk warga setempat.

Beberapa anak Asuh di LKSA Nur Hidayah bersekolah di Sekolah Negeri sehingga memungkinkan dari mereka memiliki teman yang berbeda agama. Hal tersebut bukan menjadi masalah yang besar untuk mereka, anak asuh di LKSA Nur Hidayah sudah diberikan batas-batas dalam berhubungan dengan teman non muslim. Begitu juga dengan tetangga, Ustad Dede menjelaskan bahwa pernah pihak panti melayat pada tetangga yang kebetulan memiliki agama yang berbeda. Jadi anak-anak dapat menerima baik sosialiasi berupa pemahaman mengenai toleransi beragama dan dapat diterapkan dalam kehidupan sehari-hari. Masyarakat dapat menerima baik keberadaan anak-anak dari LKSA Nur Hidayah. Hubungan yang terjalin antara keduanya sangat baik.

Modal dan habitus akan dipertaruhkan dalam sebuah ranah yang merupakan arena kekuatan yang didalamnya terdapat upaya untuk memperebutkan sumber daya (modal). Dalam pandangan bourdieu, ranah merupakan suatu sistem dan hubungan-hubungan yang membentuk suatu jaringan relasi. Ranah dalam hal ini yaitu LKSA Nur Hidayah dan lingkungan sekitar LKSA Nur Hidayah. Dalam penelitian ini hubungan antara pengasuh dengan anak maupun dengan masyarakat tergolong baik. Pengasuh menempatkan diri sebagai orangtua pengganti bagi anak asuh mereka. Bagi ustad Dede dan pengasuh lainnya pendekatan secara perlahan dan menjadi pribadi yang ramah adalah cara untuk mendekatkan diri dengan anak, mereka tidak hanya memberikan pemahaman agama melalui kajian tetapi juga aksi nyata didalam kehidupan sehari-hari. Pak Dona menjelaskan bahwa kemampuan berpikir setiap anak berbeda sehingga jika membina anak-anak tersebut harus menggunakan bahasa yang mudah dimengerti oleh anak. Masyarakat sendiri menerima keberadaan LKSA Nur Hidayah karena membawa pengaruh baik. Salah satu cara yang dilakukan masyarakat untuk menjalin hubungan dengan LKSA Nur Hidayah yaitu berkomunikasi dengan pengasuh panti untuk mengajak anak asuhnya datang ke masjid dalam rangka menghadiri pengajian yang akan diselenggarakan masyarakat. 
Praktiknya anak-anak dapat menerima dengan baik perbedaan yang ada didalam masyarakat. Sikap yang terdapat dalam toleransi dapat dilaksanakan dengan baik dalam kehidupan sehari-hari. Anak dapat mewujudkan kedamaian diantara masyarakat, memiliki sikap terbuka dan menerima perbedaan, memiliki sikap cinta, kasih sayang dan perhatian,kemudian dapat menghargai individualitas dan perbedaan. Secara tidak langsung LKSA Nur Hidayah telah memperkenalkan toleransi beragama sejak berdirinya LKSA Nur Hidayah itu sendiri, Gereja Kristen Jawa (GKJ) yang berada di belakang persis kantor dan panti putra LKSA Nur Hidayah menjadi bukti bahwa kerukunan antar umat beragama telah diajarkan dan dapat diterima dengan baik oleh anak asuh. Hubungan yang terjalin baik selama ini menjadi bukti praktik pembinaan toleransi beragama dapat diimplementasikan dalam kehidupan sehari-hari.

Tabel 2 Tabel Kesimpulan Pembahasan

\begin{tabular}{|c|c|c|c|}
\hline \multirow[b]{2}{*}{ No } & \multirow[b]{2}{*}{ Aspek } & \multicolumn{2}{|c|}{ Keterangan } \\
\hline & & LKSA & Masyarakat \\
\hline 1. & $\begin{array}{l}\text { Habitus } \\
\text { Sikap : } \\
\text { - } \\
\text { - } \text { Kedamaian } \\
\text { - } \\
\text { Terbuka } \\
\text { Penghargaan timbal } \\
\text { balik lewat } \\
\text { pemahaman yang } \\
\text { juga timbal balik } \\
\text { - } \\
\text { Benih-benih } \\
\text { intoleransi adalah } \\
\text { ketakutan dan } \\
\text { keacuhan } \\
\text { Butir-butir toleransi , } \\
\text { cinta diari oleh kasih } \\
\text { sayang dan perhatian } \\
\text { Menghargai } \\
\text { individualitas }\end{array}$ & 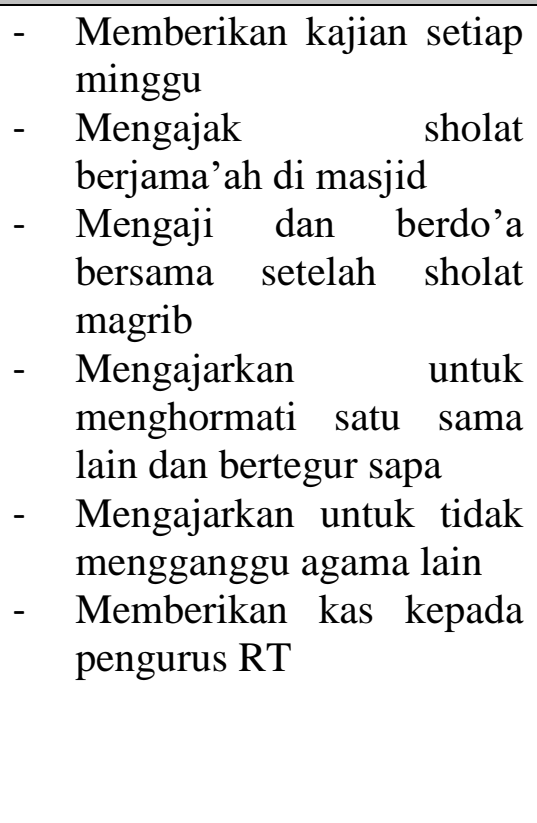 & 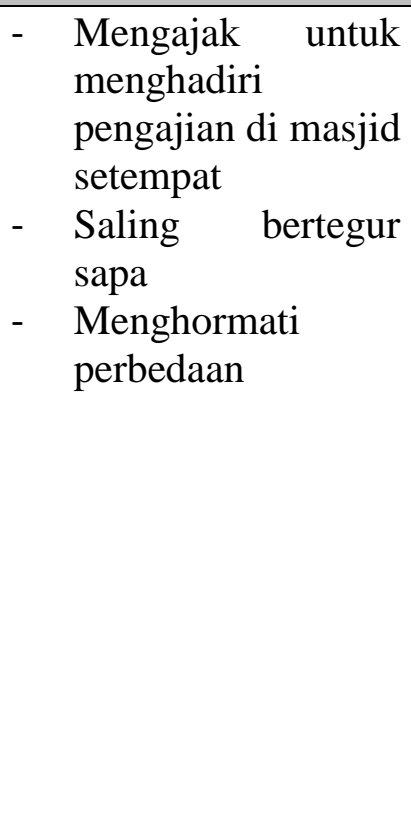 \\
\hline 2. & $\begin{array}{l}\text { Modal Sosial } \\
\text { Sikap : } \\
\text { - } \text { Terbuka dan } \\
\text { menerima } \\
\text { perbedaam } \\
\text { - Mentolerir } \\
\text { ketidaknyamanan } \\
\text { hidup } \\
\text { Butir-butir toleransi } \\
\text { adalah cinta diairi } \\
\text { oleh kasih sayang } \\
\text { dan perhatian }\end{array}$ & 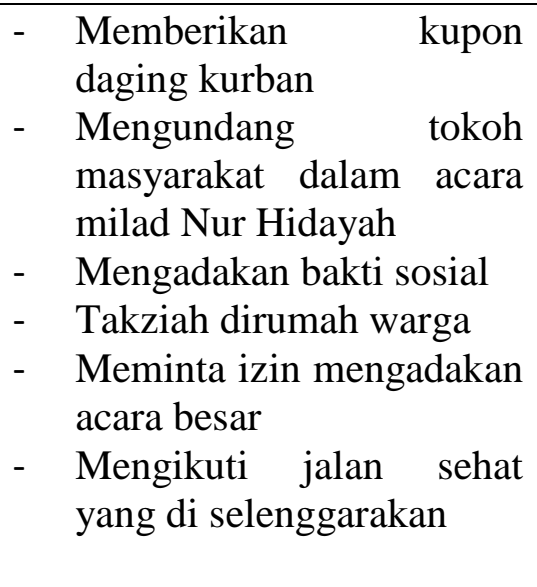 & 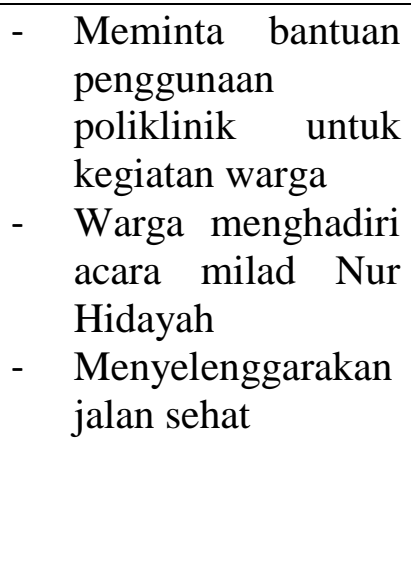 \\
\hline
\end{tabular}




\begin{tabular}{|c|c|c|c|}
\hline 3. & $\begin{array}{l}\text { Modal Budaya } \\
\text { Sikap : } \\
\text { - } \quad \text { Terbuka } \\
\text { menerima } \\
\text { perbedaan } \\
\end{array}$ & $\begin{array}{ll}\text { - } & \text { Mengikuti gotong royong } \\
\text { - } & \text { Mengikuti lomba } 17 \text { an }\end{array}$ & 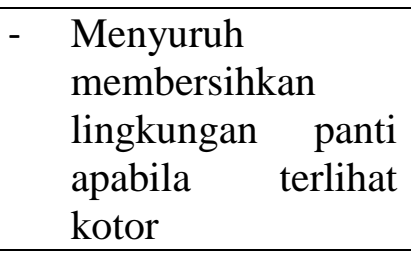 \\
\hline 4. & $\begin{array}{l}\text { Modal Simbolik } \\
\text { Benih-benih intoleransi } \\
\text { adlah ketakutan dan } \\
\text { keacuhan }\end{array}$ & 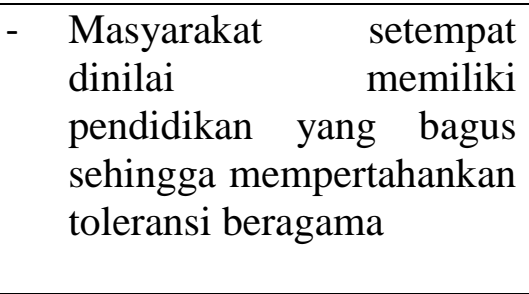 & \begin{tabular}{lr} 
- & \multicolumn{2}{l}{ Menilai anak panti } \\
berkelakuan & baik \\
karena & sudah \\
diajarkan & \\
kehidupan & \\
bertetangga. &
\end{tabular} \\
\hline 5. & Modal Ekonomi & $\begin{array}{l}\text { - } \text { Membayar pengasuh } \\
\text { untuk memberikan kajian } \\
\text { pada anak asuh } \\
\text { Mengadakan bakti sosial } \\
\text { yang diperuntukan untuk } \\
\text { warga } \\
\text { - Membiayai sekolah anak } \\
\text { asuh dari jenjang } \\
\text { SD,SMP,SMA } \\
\text { Memberi uang saku untuk } \\
\text { kegiatan yang berkaitan } \\
\text { dengan sekolah. }\end{array}$ & $\begin{array}{ll}\text { - } & \text { Mengadakan jalan } \\
\text { sehat } & \text { yang } \\
\text { diperuntukan untuk } & \text { umum }\end{array}$ \\
\hline
\end{tabular}

\section{PENUTUP}

Dalam penelitian ini dapat disimpulkan bahwa keluarga merupakan lembaga yang paling penting dalam membentuk sikap anak namun tidak dengan sebagian anak yang kurang beruntung seperti yatim, piatu ,yatim piatu dan berasal dari keluarga yang kurang mampu. Jalan keluar dalam permasalahan tersebut adalah memasukkan anak ke dalam panti asuhan dan disini LKSA Nur Hidayah berperan sebagai pengganti keluarga di rumah untuk membentuk perilaku anak asuh dalam hal sosial,keterampilan maupun agama. Sesuai dengan penelitian ini berfokus pada pembinaan di LKSA Nur Hidayah untuk membentuk perilaku toleransi beragama pada anak di kalangan masyarakat.

LKSA Nur Hidayah pada hakikatnya merupakan lembaga yang bertugas sebagai pengganti fungsi keluarga di rumah sehingga dalam proses pengajarannya tidak hanya diberikan ilmu mengenai agama namun juga mengenai kehidupan sosial. Hal terpenting yang diajarkan LKSA Nur Hidayah pada anak tentang perilaku toleransi beragama yaitu boleh berteman dengan siapapun tanpa memandang agama dan memberikan hak tetangga sebagaimana mestinya meskipun terdapat perbedaan agama, di sisi lain meskipun diberikan kebebasan untuk berteman, berinteraksi dengan orang yang memiliki perbedaan agama anak asuh di ajarkan untuk tetap menjaga akidah dengan baik dan berpegang sesuai dengan tuntunan agama.

Sejauh ini anak-anak di LKSA Nur Hidayah dapat mempraktekan ke dalam kehidupan sehari-hari hal-hal yang diajarkan oleh pengasuhnya, tidak semua anak bersekolah di sekolah berbasis Islam sehingga tidak memungkiri bahwa beberapa anak memiliki teman 
yang memiliki latar belakang agama yang berbeda dengan mereka. Dalam pemikiran anak toleransi itu tidak boleh menganggu agama lain, dan tidak boleh menjelekan agama lain. Toleransi beragama menurut mereka penting sehingga mereka saat ini bisa menerima dan bisa hidup di antara perbedaan. Apabila terdapat anak yang melanggar aturan maka akan diberi sanksi sesuai dengan usia dan kesepakatan bersama, sanksi paling berat adalah dikembalikan kepada keluarga.

\section{DAFTAR PUSTAKA}

Bourdieu, P.1990.The logic of practise.California:Stanford University Press dalam jurnal idea societa berjudul Modal Praktik Sosial Sosialita oleh Kartika Sunuwati tahun 2015

Silalahi, Ulber. 2012. Metode Penelitian Sosial. Bandung: Refika Aditama.

Slamet, Yulius. 2006. Metode Penelitian Sosial. Surakarta: UNS Press

Purwawidada,Fajar.2014.Jaringan Teroris Solo dan Implikasinya terhadap Keamanan Wilayah serta Strategi Penanggulangannya (Studi di Wilayah Solo Jateng. Thesis.Universitas Gadjah Mada

Wisnu Winardi. 2016. Agama di Indonesia dalam https://www.indonesiainvestments.com/id/budaya/agama/item69? Diakses pada 14 Februari 2019 pukul 18.21 WIB

Ayatullah. 2017. Sara dan Toleransi ditulis dalam https://www.qureta.com/post/sara-dantoleransi Diakses pada 14 Februari 2019 pukul 19.01 WIB.

Luthfia Ayu Azanella . 2019. "CEK FAKTA:Jokowi Sebut Ada 714 Suku dan 1.001 Bahasa di Indonesia", https://nasional.kompas.com/read/2019/03/30/21441421/cek-faktajokowi-sebut-ada-714-suku-dan-1001-bahasa-di-indonesia. Di akses pada 6 Oktober 2019 pukul 07.55 WIB

Nazar Nurdin. 2018. LSM ElSA: tahun 2018 praktik intoleransi meningkat di Jawa Tengah https://regional.kompas.com/read/2019/01/31/12585281/lsm-elsa-tahun-2018praktik- intoleransi-meningkat-di-jawa-tengah. Diakses pada 15 Februari 2019 Pukul 06.45 WIB

Scholastica Gerintya . 2018. Benarkah intoleransi antar umat beragama meningkat?https://tirto.id/benarkah-intoleransi-antar-umat-beragama-meningkat$\begin{array}{llllllll}\mathrm{cEPz} & \text { Diakses } & \text { pada } & 15 & \text { Februari } 2019 & \text { Pukul } & 07.30 & \text { WIB }\end{array}$ http://KBBI.web.id/bina di akses pada 17 Februari 2019 pukul 05.00 WIB 